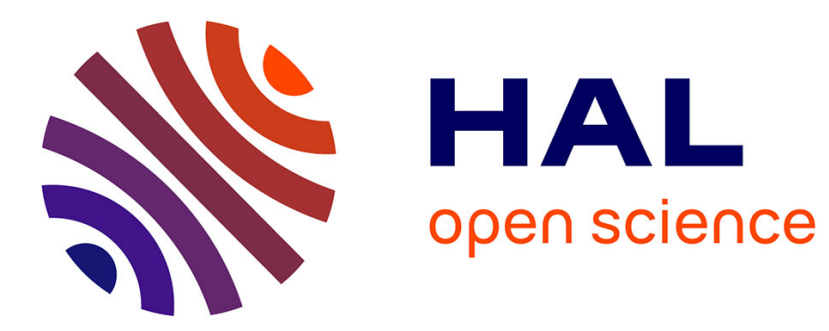

\title{
Of mice and men: innate immunity in pneumococcal pneumonia
}

\author{
Esther Calbo, Javier Garau
}

\section{To cite this version:}

Esther Calbo, Javier Garau. Of mice and men: innate immunity in pneumococcal pneumonia. International Journal of Antimicrobial Agents, 2009, 35 (2), pp.107. 10.1016/j.ijantimicag.2009.10.002 . hal-00556377

\section{HAL Id: hal-00556377 \\ https://hal.science/hal-00556377}

Submitted on 16 Jan 2011

HAL is a multi-disciplinary open access archive for the deposit and dissemination of scientific research documents, whether they are published or not. The documents may come from teaching and research institutions in France or abroad, or from public or private research centers.
L'archive ouverte pluridisciplinaire HAL, est destinée au dépôt et à la diffusion de documents scientifiques de niveau recherche, publiés ou non, émanant des établissements d'enseignement et de recherche français ou étrangers, des laboratoires publics ou privés. 


\section{Accepted Manuscript}

Title: Of mice and men: innate immunity in pneumococcal pneumonia

Authors: Esther Calbo, Javier Garau

PII: $\quad$ S0924-8579(09)00463-4

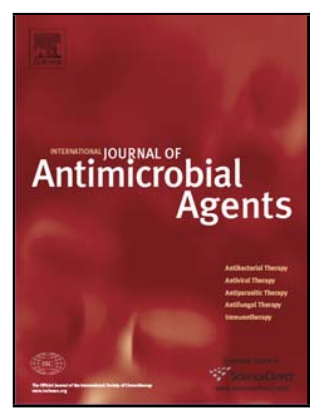

DOI: doi:10.1016/j.ijantimicag.2009.10.002

Reference: ANTAGE 3152

To appear in:

International Journal of Antimicrobial Agents

Received date: 5-10-2009

Accepted date: 6-10-2009

Please cite this article as: Calbo E, Garau J, Of mice and men: innate immunity in pneumococcal pneumonia, International Journal of Antimicrobial Agents (2008), doi:10.1016/j.ijantimicag.2009.10.002

This is a PDF file of an unedited manuscript that has been accepted for publication. As a service to our customers we are providing this early version of the manuscript. The manuscript will undergo copyediting, typesetting, and review of the resulting proof before it is published in its final form. Please note that during the production process errors may be discovered which could affect the content, and all legal disclaimers that apply to the journal pertain. 


\section{Of mice and men: innate immunity in pneumococcal pneumonia}

Esther Calbo ${ }^{\mathrm{a}, \mathrm{b}, *}$, Javier Garau ${ }^{\mathrm{a}}$

a Service of Internal Medicine, Infectious Disease Unit, Hospital Universitari

Mútua de Terrassa, Plaza Dr Robert 5, 08221 Terrassa, Barcelona, Spain

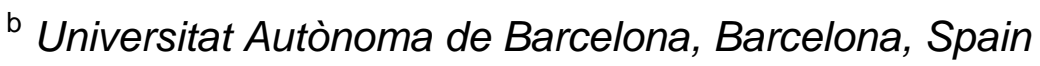

\section{ARTICLE INFO}

Article history:

Received 5 October 2009

Accepted 6 October 2009

Keywords:

Innate immune system

Inflammatory response

Cytokines

Streptococcus pneumoniae

Pneumonia

* Corresponding author. Tel.: +34 937365050 x3931; fax: +34 937365037 .

E-mail address: esthercalbo@hotmail.com (E. Calbo). 


\section{ABSTRACT}

Pneumococcal pneumonia is characterised by an intense inflammatory response induced mainly by cell wall components of the bacterium. Recognition of cell wall components by Toll-like receptors (TLRs) induces intracellular signalling pathways that culminate in the activation of pro-inflammatory genes through nuclear factor $\kappa \mathrm{B}(\mathrm{NF}-\kappa \mathrm{B})$. Tumour necrosis factor-alpha $(\mathrm{TNF} \alpha)$ is one of the earliest mediators produced and induces a second wave of pro- and antiinflammatory cytokines that orchestrate the immune response. The magnitude of this response in patients with pneumococcal pneumonia is a complex network and many factors must be considered in the analysis of the cytokine production pattern. First, bacterial growth and the inflammatory response are dynamic processes, produced initially as a local phenomenon with a late systemic extension. Second, host characteristics, such as different cytokine gene polymorphisms, can cause a distinct immune response. Finally, other microorganism determinants and even the immunomodulatory effect of antimicrobials may play a role in cytokine production. Recent data on innate immunity against Streptococcus pneumoniae gathered from the murine model of pneumonia, from studies of human genetic polymorphisms associated with increased susceptibility to pneumococcal infection, and from human clinical trials are discussed. Special emphasis has been placed on the description of the chronology of the complex network of innate immunity triggered by pneumococcal infection. 
But Mouse, you are not alone,

In proving foresight may be vain:

The best laid schemes of mice and men

Go often askew,

And leave us nothing but grief and pain,

For promised joy!

Robert Burns on 'To A Mouse, on Turning Her Up in Her Nest, with the Plough' 


\section{Introduction}

Streptococcus pneumoniae remains the most common identifiable cause of pneumonia leading to hospitalisation. Mortality from pneumococcal infection decreased significantly with the advent of antibiotic therapy. However, despite the advances in diagnostic methods and in intensive care support, mortality among patients with pneumococcal pneumonia remains high, ranging from $5 \%$ to $35 \%[1-3]$.

In 1964, Austrian and Gold [4] observed that in patients with pneumococcal bacteraemia deaths occurring within the first 5 days of treatment were similar among those treated with penicillin, serum or even in untreated patients. The authors concluded that 'antimicrobial therapy has little or no impact upon the outcome of infection among those destined at the onset of illness to die'. This could be due to the capacity of invading pathogens to trigger an inappropriate inflammatory response that can become independent of bacterial presence and lead to multiple organ failure and death.

The innate immune system represents the first non-specific step in host defence. It constitutes the earliest response to invading microbes and acts to contain infection in the first minutes to hours of challenge. Through a wide range of mechanisms, including phagocytosis, intracellular killing and activation of pro-inflammatory or antiviral cytokine production, the cells of the innate immune system initiate and support adaptive immunity. 
In this article, the most recent information on innate immunity against $S$. pneumoniae is discussed. Data reviewed include the murine model of pneumococcal pneumonia, human genetic polymorphisms associated with an increased risk of pneumococcal infection, and human clinical trials. Special interest has been taken to describe the chronology of the complex network activation of innate immunity triggered by pneumococcal infection.

\section{Innate immune response in pneumococcal pneumonia}

A prerequisite for the initiation of a host response is the recognition of pathogens by the host immune system. The bronchial and lung epithelium act as a mechanical barrier and as a sentinel system against pathogens [5]. Recognition is performed by a set of diverse receptors called pattern recognition receptors that are located on the cell surface of the epithelial barrier and on haematopoietic cells. These receptors, such as the Toll-like receptors (TLRs), bind microorganism molecular moieties [6]. It has been shown that cell wall components of pneumococci (lipoteichoic acid and peptidoglycan) are recognised by TLR-2 [7] and there is some evidence suggesting that the inflammatory response of murine macrophages to the pneumococcal toxin pneumolysin depends on TLR-4, as mutant mice that lack TLR-4 are significantly more susceptible to invasive disease and death following infection with wild-type pneumococci compared with control mice [8].

TLR-2 renders only a modest contribution in the mouse pneumococcal model, as no differences have been found between wild-type and TLR-2 knock-out animals in terms of bacterial clearance and morbidity [9]. Some authors 
consider that TLR-9 may also play a role in the recognition of $S$. pneumoniae.

Owing to the autolytic nature of this microorganism, DNA is released, which has been shown to be recognised by TLR-9 [10].

The intracellular signalling pathways triggered by these diverse pattern recognition receptors are complex and include, among others, molecules such Mal and interleukin-1 receptor-associated kinase 1 (IRAK-1) and interleukin-1 receptor-associated kinase 4 (IRAK-4). Following stimulation of TLR-2 or TLR4, the adaptor protein Mal triggers the signalling cascade, which culminates in the activation of pro-inflammatory genes through nuclear factor $\kappa B(N F-\kappa B)$. Heterozygous carriage of a variant of this protein has been associated with protection from invasive pneumococcal disease (IPD) in humans [11]. The protective heterozygote state is likely to be associated with attenuated signalling and reduced NF-kB activation. Inherited IRAK-4 deficiency has also been associated with severe and recurrent IPD in children [12]. In the absence of IRAK-4, agonists of TLR do not induce the production of major inflammatory cytokines and growth factors in whole blood cells and peripheral blood mononuclear cells.

These signalling pathways converge on the NF- $\mathrm{kB}$ and interferon regulatory factor families [13]. Activation of NF-kB occurs following stimulation of a variety of immune receptors, including TLRs and members of the interleukin (IL)-1 and tumour necrosis factor (TNF) receptor superfamilies. In unstimulated cells, NF$\kappa B$ transcription factors are prevented from binding DNA owing to their association with the inhibitors of NF- $\mathrm{KB}(\mathrm{I} \kappa \mathrm{B})$ protein family; phosphorylation of 
the $I_{\kappa} B$ inhibitors by the $I_{\kappa} B$ kinase complex leads ultimately to their degradation and the release of $\mathrm{NF}-\kappa \mathrm{B}$, which is then capable of inducing gene transcription [14]. Some human polymorphisms in the $I_{\kappa} B$ genes have been associated with susceptibility to IPD [15]. NF-kB is essential for cytokine expression, neutrophil recruitment and bacterial killing in pneumococcal pneumonia. TLR-2, expressed on the surface of type II alveolar epithelial cells, has been shown to allow S. pneumoniae-induced NF-kB activation in this cell type [16]. Two NF-kB proteins (RelA and p50) translocate to the nucleus in response to pneumococcal stimuli. RelA is essential for the transcription of chemokines and adhesion molecules that mediate neutrophil recruitment [17], and interrupting RelA compromises the clearance of bacteria from mouse lungs [18]. In contrast, p50 limits expression of these and other pro-inflammatory genes. Interrupting p50 increases mortality by exacerbating acute lung injury despite effective bacterial clearance [19]. Thus, a good outcome from pneumococcal pneumonia requires the balance of these two NF-kB proteins RelA and p50 with opposing actions on gene expression.

The TNF $\alpha$ cascade is also activated in the airway epithelium and alveolar macrophages by bacteria. TNF $\alpha$ is a critical early upstream cytokine in pneumococcal pneumonia in combination with IL-1. TNF $\alpha$ and IL-1 induce the

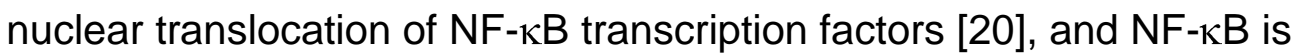
necessary and sufficient for neutrophil recruitment in pneumococcal pneumonia. In fact, neutrophil recruitment is significantly decreased by deficiency of receptors for TNF $\alpha$ and IL-1 ( $\alpha$ and $\beta$ ) [21] in this setting; however, there is a 
functional redundancy between these two cytokines, such that the presence of one can largely compensate for absence of the other [17].

Administration of anti-TNF $\alpha$ antibody worsens the course of pneumococcal pneumonia in the mouse model as it increases the number of infecting bacteria in the blood, decreases neutrophil counts and accelerates death of infected mice [22]. In humans, an increased risk of opportunistic infections as well as pneumococcal invasive disease has been described in patients on therapy with monoclonal anti-TNF $\alpha$ antibodies [23,24]. Conversely, excessive TNF $\alpha$ production, via its effects on neutrophil activation, contributes to lung injury in a variety of diseases $[25,26]$ and increases the risk of septic shock and death [27]. Moreover, an association with greater risk of shock and death has been described in patients with a TNF $\alpha$ high-secretor profile, linked to polymorphisms in the lymphotoxin $\alpha+250$ locus [28] and also the TNF $\alpha-238$ locus [29]. In addition, TNF $\alpha$ can cause upregulation of receptors implicated in tissue invasion of pneumococci, such as the platelet-activating factor receptor, increasing the risk of bacteraemia [30].

Alveolar macrophages (AMs) and dendritic cells are essential in phagocytosis of bacteria and in co-ordinating the innate response to infection [31]. AMs are the major source of TNF $\alpha$ in pneumococcal pneumonia [32]. In established pneumonia, AMs also contribute to resolution of the inflammatory response but are no longer critical for bacterial clearance as neutrophils become the major cell phagocytosing bacteria [33]. Host-mediated macrophage apoptosis is a necessary feature in pneumococcal infection, and phagocytosis of apoptotic 
AMs contributes to resolution of inflammation in the lung, and reduces TNF $\alpha$ expression, neutrophil recruitment and IPD [34].

Neutrophil action is extremely necessary to achieve $S$. pneumoniae clearance and is crucial for resolution of pneumococcal pneumonia [35]. The ability of neutrophils to combat pneumococci is due to a number of specific activities, including adherence to blood vessel walls, chemotaxis, phagocytosis and microbial killing. The innate immune response increases the rate of neutrophil production from the bone marrow, shortens their maturation time and stimulates the release both of mature and immature neutrophils into the circulation [36]. Adherence to blood vessel walls involves the interaction of specific ligands on neutrophils with receptors on endothelial cells, a process extensively regulated by cytokines IL-1 and TNF, among others [37]. Chemokines, such as IL-8, induced by TNF $\alpha$ and IL-1 through the NF-kB system, stimulate chemotaxis and influence the directional motility of neutrophils. Chemokine expression in pneumococcal pneumonia is much more dependent on receptors for TNF $\alpha$ and IL-1 than in Gram-negative bacterial pneumonia [21]. Finally, binding and ingestion of microorganisms take place when neutrophils recognise serum opsonins (complement and immunoglobulins attached to pneumococci) or specific sugars. Phagocytosis facilitates effective killing by trapping a particle in a phagosome where it can be subjected to high concentrations of microbicidal molecules [37].

Many other cytokines are known to be involved in antipneumococcal defence within the lung. IL-6 has been ascribed both pro- and anti-inflammatory effects. 
IL-6 delays neutrophil apoptosis and enhances neutrophil cytotoxic function, including oxygen radical production [38]. IL-6 is a major inducer of acute phase proteins, including C-reactive protein (CRP), and in community-acquired pneumonia (CAP) a positive correlation between IL-6 and CRP levels has been reported [39]. Adaptive immune mechanisms such as T-cell proliferation, the development of antigen-specific cytotoxic T-lymphocytes and B-cell stimulation are also dependent upon IL-6 [40]. A human genotype that has been associated with increased inducibility of IL-6 appears to protect patients from bacterial dissemination during S. pneumoniae infection [41].

Regulation of the inflammatory response by anti-inflammatory cytokines prevents further damage. IL-10 contributes by reducing the production of proinflammatory cytokines and chemokines [42]. Mice lacking any IL-10 response have higher lethality due to septic shock, possibly because of uninhibited proinflammatory reactions [43]. Also, levels of IL-10 are higher in patients with sepsis and septic shock, and non-survivors of sepsis have persistently raised levels of IL-10 while survivors show decreasing IL-10 levels over time [44]. Likewise, a polymorphism in the IL-10 gene promoter (-108G/A) associated with increased IL-10 release correlates with greater severity and mortality in patients with CAP $[45,46]$. Taken together, these data indicate that IL-10 is necessary to counterbalance pro-inflammatory reactions, although IL-10 overexpression might increase mortality due to unresolved infection.

Two acute phase proteins play an important role in pneumococcal infection, mannose-binding lectin (MBL) and CRP. Both are produced in the liver during 
the acute phase response and act first by binding to the cell wall of $S$. pneumoniae activating the classical complement pathway, and second by opsonising bacteria and promoting phagocytosis by neutrophils $[47,48]$. In addition, natural non-specific immunoglobulin $\mathrm{M}(\lg \mathrm{M})$ antibodies are produced in pneumococcal infection; they bind to the microbial surface and activate complement through the classical pathway. CRP bound to pneumococcal phosphocholine, a constituent of the pneumococcal teichoic and lipoteichoic acids that make up C-carbohydrate, activates the classical pathway of complement enhancing opsonophagocytosis of the microorganism [49]. In humans, a variant in the CRP gene has been associated with greater susceptibility to IPD [50]. Recognition of carbohydrate on the pneumococcal surface by MBL also activates complement. Recently, homozygotes for a MBL codon variant have been shown to present an increased risk of IPD in a population of White individuals [51].

\section{The immune response as a dynamic process}

Infection is a dynamic process and time represents one of the main contributors to bacterial growth. Data suggest that time can be a critical factor in the evolution of sepsis.

The chronology of pneumococcal infection has been well described in the animal model (Table 1). Despite differences in the inoculum and serotype used, and in specific host responses, these experiments are also good predictors of the chronology of human infection. In the mouse model [52], following

inoculation of $10^{7}$ log-phase colony-forming units (CFU) of S. pneumoniae 
serotype 3, all animals become bacteraemic and mortality was $100 \%$ in the control group. In this model, five chronological stages are described. In step 1 (between $0 \mathrm{~h}$ and $4 \mathrm{~h}$ after infection) there is partial but ineffective bacterial clearance by resident alveolar macrophages, accompanied by the activation of cytokines [TNF and IL-6 in bronchoalveolar lavage (BAL) fluid; TNF, IL-6 and IL1 in lung tissue; and IL-6 in serum] and transient nitric oxide (NO) release in BAL fluid, which leads to physiological and haematological abnormalities. In step 2 (4-24 h) there is bacterial growth in alveoli and recruitment of neutrophils from the bloodstream to lung tissue and alveoli, associated with high release of all three cytokines and leukotriene B4 (LTB4) at the infected site and transient spill over of IL-1 in serum. In step $3(24-48 \mathrm{~h})$ there is downregulation of proinflammatory cytokines (TNF and IL-1) in BAL fluid and lungs, but tissue injury become visible and the regeneration processes start concomitant with progression of bacteria to tissue and blood. In step 4 (48-72 h) a sharp reduction in blood leukocytes and a gradual recruitment of monocytes and lymphocytes to BAL fluid is observed; LTB4 and NO levels are very low in serum but increased in BAL fluid, corresponding to monocyte migration; bacteraemia is associated with activation of cytokines (TNF and IL-6). Finally, in step 5 (72-96 h) pulmonary histopathological features include severe air-space disorganisation with loss of alveolar architecture and diffuse tissue damage that coincides with high NO and malondialdehyde levels recovered in BAL fluid; lung weight is further increased, and there is unrestrained bacterial growth, loss in body weight and death. 
In a similar experiment but with a lower inocula [53] $\left(5 \times 10^{4} \mathrm{CFU}\right.$ of $S$. pneumoniae), two groups of animals were compared: those with a low CFU count in BAL fluid $\left(<10^{4} \mathrm{CFU} / \mathrm{g}\right)$, defined as the recovering group, which coincided with health status; and the sick group, which presented a progressive increase in CFU count in BAL fluid. In the latter group, bacterial growth was shown to reach a plateau of $10^{7} \mathrm{CFU} / \mathrm{g}$ lung tissue $48 \mathrm{~h}$ post inoculation. However, the inflammatory response further amplified after $36 \mathrm{~h}$ and peak levels of most mediators were observed $84 \mathrm{~h}$ post infection. This late burst of inflammation was most likely due to lysis of dying pneumococci and release of large amounts of toxins rather than by living pneumococci in a well established infection. In this model, IL-6 levels in blood increased progressively in the sicker animals and correlated with the presence of bacteraemia, and no other inflammatory mediators were detected in blood. In lung tissue, IL-6 concentrations remained steady and low for the recovering group but increased in the sick group, reaching statistical significance at $84 \mathrm{~h}$ post infection. Levels of IL-1 $\beta$ were also higher in the sick group from $24 \mathrm{~h}$ post infection until death. On the other hand, in the group of mice with higher bacterial growth, more animals became bacteraemic concomitant with the progression of pulmonary infection (25\% at $36 \mathrm{~h}, 60 \%$ at $60 \mathrm{~h}$ and $100 \%$ at $84 \mathrm{~h})$. Higher levels of inflammatory mediators were also observed as bacteria reached the bloodstream. Injection of TNF or the addition of lipopolysaccharide or heat-killed S. pneumoniae to the inoculum enhanced the early host response and survival. 


\section{Cytokines and pneumonia: from mice to human studies}

Few human studies have explored the evolution of cytokine production over time in pneumonia (Table 2). The studied populations are very heterogeneous, with great disparity in terms of their aetiology, observational periods and mortality rates.

Patients studied have included those with CAP and a few of them with ventilator-associated or hospital-acquired pneumonia. Only a few studies have been conducted in a homogeneous group of patients with documented pneumococcal pneumonia $[59,67,68]$. The observation period ranged from $0-12$ $\mathrm{h}$ to 10 days from inclusion, with a variable period of daily determination of cytokine levels. Mortality ranged from $3.4 \%$ [39] to $50 \%$ [60].

The most frequently studied cytokines were TNF $\alpha$, IL-6, IL-1 $\beta$, IL-8 and IL-10 and IL-2 receptor (IL-2R). In most studies [54,61,62,66,67], patients were found to have high baseline levels of systemic cytokines at entry, suggesting that the cytokine cascade was already fully activated by the time patients sought hospital care. Sequential determinations showed a pattern of decline with progressive normalisation of all pro- and anti-inflammatory cytokines detected that was accompanied by clinical recovery. In the studies with a shorter observational period, that is those with only hourly determinations, no variations in cytokine levels were found [64,63], indicating that the kinetics of cytokine production takes days to produce detectable changes. Plasma levels remained elevated or were higher than on admission in some of the patients who died $[61,67]$. 
It is noteworthy that systemic cytokine levels could be determined in only a low proportion of patients $[55,61,66,67]$. The advocated causes to explain the absence of detectable concentrations in serum were the local production and rapid clearance, the short half-life of most cytokines, the number and timing of the sequential determinations in each study, the degree of lung injury, and the different aetiologies implicated in the process $[39,61]$. It seems that only in severe CAP the development of an intense and maintained inflammatory local response can produce a systemic extension of cytokine release.

A correlation between severity and cytokine concentrations has not been well established and data on this association are full of contradictory evidence [54]. It seems, however, that high IL-6 $[39,58,60,61,65,66]$ and probably IL-8 levels [58] are the best predictors of increased severity and mortality. Persistent and concomitant elevation both of pro- and anti-inflammatory cytokines may be particularly significant, as will be commented below [66].

Cytokine production is a compartmentalised phenomenon and this fact may explain both the low proportion of patients with detectable cytokine levels in serum and the poor correlation between serum levels and illness severity and outcome. Consistent with this fact, high levels of TNF, IL-1 and IL-6 have been found in samples obtained by BAL at the site of infection in unilateral pneumonia, whereas much lower levels were present in the contralateral nonaffected lung [69] and in serum [60]. 
Only one study has analysed the relationship between bacterial burden and sequential cytokine concentrations in BAL fluid. The investigators could not show any significant correlation, although it must be taken into account that all included patients were on antimicrobial therapy [60].

The duration of illness may influence cytokine levels at admission. No correlation was found in the study by Ortqvist et al. [39] between time from onset of symptoms and IL-6. In contrast, we have recently shown that in pneumococcal pneumonia, patients with a longer time of evolution presented with higher levels of pro-inflammatory cytokines and a higher expression of acute phase proteins, suggesting a sustained release of pneumococcal antigens over time [68].

Age-related changes in cytokine production over time have been analysed in two studies $[59,69]$. In both, lower cytokine concentrations and prolonged inflammatory activity were observed in elderly patients, a phenomenon attributed to immunosenescence.

Only two studies have provided enough data to compare levels of cytokines among patients with pneumonia of different aetiologies [39,62]. Bacteraemic pneumococcal pneumonia was associated with the highest concentrations of IL6 [39]. Legionella pneumonia patients displayed higher initial concentrations of TNF, IL-6, IL-8 and IL-10. However, after 24 h, serum IL-6, IL-8 and IL-10 concentrations increased in the pneumococcal infections but decreased markedly in the Legionella group. In pneumococcal pneumonia, the initial 
increase in cytokine levels has been related to bacterial lysis caused by $\beta$ lactams. It could be that with the onset of antibiotic-induced bacterial lysis, a release of cell wall components exacerbates inflammation [62]. Likewise, cytokine concentrations have been shown to be higher in bacteraemic compared with non-bacteraemic patients $[62,68]$.

We have recently examined the impact of antimicrobial therapy on cytokine production in pneumococcal pneumonia [67]. We sought to compare the evolution of pro- and anti-inflammatory systemic cytokine levels over time in patients with severe pneumococcal pneumonia treated either with a $\beta$-lactam (ceftriaxone) or a fluoroquinolone (levofloxacin). The levofloxacin-treated group showed a shorter time to clinical stability (expressed as an earlier recovery of $\mathrm{O}_{2}$ saturation and a slower cardiac rate) in parallel with lower TNF $\alpha$ levels. The ability of fluoroquinolones to inhibit cytokine production coupled with the $\beta$ lactam cell wall activity (that might result in a second wave of TNF $\alpha$ production) could explain these findings.

The most extensive study published so far on cytokines and pneumonia included 1886 adult patients with CAP admitted to hospital from the Emergency Department [66]. Patients who developed sepsis and survived were compared with those who developed sepsis and died and with those who never developed sepsis. Many interesting observations are reported in this study. Remarkably, $8 \%, 57 \%$ and $53 \%$ of patients displayed normal levels of IL-6, TNF and IL-10 in blood samples, respectively. At the time of admission, cytokine concentrations had already peaked and very few patients had markedly elevated levels later. 
Cytokine levels remained elevated throughout the hospital course and for much longer than clinical signs. No increase in cytokine levels was detected in relation to the onset of organ dysfunction. The highest risk of death was seen in patients who expressed high levels of both IL-6 and IL-10, with the lowest mortality in the group with medium or low IL-6 concentrations combined with low IL-10 concentrations.

Many anti-inflammatory strategies have failed to improve survival in pneumonia [13]. It appears that timing is crucial to achieve optimal modulation of the inflammatory response. In the mouse model, increased survival has been observed when pro-inflammatory compounds were injected concomitant with the inoculum, suggesting that a stronger inflammatory response in the early hours of infection can be beneficial [53]. By the same token, when anti-TNF $\alpha$ was administered together with antibiotic $25 \mathrm{~h}$ after the induction of pneumococcal pneumonia, it led to decreased survival and was associated with enhanced bacterial outgrowth [70]. This could be due to the ability of pneumococci to inhibit some components of the host defence in the early stages of infection and hence continue its multiplication without being eliminated $[71,72]$. In clinical practice, patients arrive at hospital in a wide range of stages of infection and the key to improving the management of the inflammatory response could be to select those severely ill patients in the very early phases of the infection that could benefit from the use of an inflammatory modulator. 


\section{Conclusions}

Pneumococcal infection triggers a complex network. Innate immunity acts as a first non-specific step in host defence, initiated by pathogen recognition, which is achieved through a limited set of encoded receptors. These receptors trigger intracellular signalling pathways that converge on signalling hubs such as

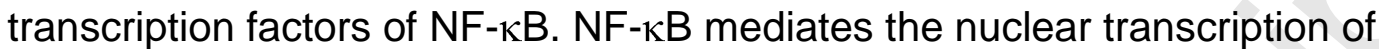
cytokines such as TNF $\alpha$ and other molecules in a dynamic process that requires a balanced pro- and anti-inflammatory response. Single nucleotide polymorphisms occur regularly in genes involved in the host response to $S$. pneumoniae and some have been associated with an impaired response. Many of the studies carried out on genetic polymorphisms have important methodological limitations and caution should be taken when interpreting the results. However, all these studies taken together strongly support the idea that genetics may explain increased susceptibility to pneumococcal infection. The immune response to infection is a dynamic process, changing over time. Initially it is a compartmentalised phenomenon, which may be followed by a systemic extension beyond the lung. Many factors can interact with this response such the duration of illness, aetiology, some host characteristics and even the immunomodulatory activity of the antimicrobial therapy used.

\section{Funding}

None.

\section{Competing interests}

None declared. 


\section{Ethical approval}

Not required. 


\section{References}

[1] Brandenburg JA, Marrie TJ, Coley CM, Singer DE, Obrosky DS, Kapoor WN, et al. Clinical presentation, processes and outcomes of care for patients with pneumococcal pneumonia. J Gen Intern Med 2000;15:638-46.

[2] Ortqvist A, Grepe A, Julander I, Kalin M. Bacteremic pneumococcal pneumonia in Sweden: clinical course and outcome and comparison with non-bacteremic pneumococcal and mycoplasmal pneumonias. Scand $J$ Infect Dis 1988;20:163-71.

[3] Afessa B, Greaves WL, Frederick WR. Pneumococcal bacteremia in adults: a 14-year experience in an inner-city university hospital. Clin Infect Dis $1995 ; 21: 345-51$.

[4] Austrian R, Gold J. Pneumococcal bacteremia with especial reference to bacteremic pneumococcal pneumonia. Ann Intern Med 1964;60:759-76.

[5] Hippenstiel S, Opitz B, Schmeck B, Suttorp N. Lung epithelium as a sentinel and effector system in pneumonia-molecular mechanisms of pathogen recognition and signal transduction. Respir Res 2006;7:97.

[6] Akira S, Uematsu S, Takeuchi O. Pathogen recognition and innate immunity. Cell 2006;124:783-801.

[7] Yoshimura A, Lien E, Ingalls RR, Tuomanen E, Dziarski R, Golenbock D. Cutting edge: recognition of Gram-positive bacterial cell wall components by the innate immune system occurs via Toll-like receptor 2. J Immunol 1999;163:1-5.

[8] Malley R, Henneke P, Morse SC, Cieslewicz MJ, Lipsitch M, Thompson CM, et al. Recognition of pneumolysin by Toll-like receptor 4 confers resistance to pneumococcal infection. Proc Natl Acad Sci USA 2003;100:1966-71. 
[9] Knapp S, Wieland CW, van't Veer C, Takeuchi O, Akira S, Florquin S, et al. Toll-like receptor 2 plays a role in the early inflammatory response to murine pneumococcal pneumonia but does not contribute to antibacterial defense. $\mathrm{J}$ Immunol 2004;172:3132-8.

[10] Paterson GD, Mitchell TJ. Innate immunity and the pneumococcus. Microbiology 2006;152:285-93.

[11] Khor CC, Chapman SJ, Vannberg FO, Dunne A, Murphy C, Ling EY, et al. A Mal functional variant is associated with protection against invasive pneumococcal disease, bacteremia, malaria and tuberculosis. Nat Genet 2007;39:523-8.

[12] Ku CL, von Bernuth H, Picard C, Zhang SY, Chang HH, Yang K, et al. Selective predisposition to bacterial infections in IRAK-4-deficient children: IRAK-4-dependent TLRs are otherwise redundant in protective immunity. J Exp Med 2007;204:2407-22.

[13] Mizgerd JP. Acute lower respiratory tract infection. N Engl J Med 2008;358:716-27.

[14] Tergaonkar V, Correa RG, Ikawa M, Verma IM. Distinct roles of IאB proteins in regulating constitutive NF-אB activity. Nat Cell Biol 2005;7:921-3.

[15] Chapman SJ, Khor CC, Vannberg FO, Frodsham A, Walley A, Maskell NA, et al. IкB genetic polymorphisms and invasive pneumococcal disease. Am J Respir Crit Care Med 2007;176:181-7.

[16] Schmeck B, Huber S, Moog K, Zahlten J, Hocke AC, Opitz B, et al. Pneumococci induced TLR- and Rac1-dependent NF-kB-recruitment to the IL-8 promoter in lung epithelial cells. Am J Physiol Lung Cell Mol Physiol 2006;290:L730-7. 
[17] Quinton LJ, Jones MR, Simms BT, Kogan MS, Robson BE, Skerrett SJ, et al. Functions and regulation of NF-kB RelA during pneumococcal pneumonia. J Immunol 2007;178:1896-903.

[18] Alcamo E, Mizgerd JP, Horwitz BH, Bronson R, Beg AA, Scott M, et al. Targeted mutation of TNF receptor I rescues the RelA-deficient mouse and reveals a critical role for NF-kB in leukocyte recruitment. J Immunol $2001 ; 167: 1592-600$.

[19] Mizgerd JP, Lupa MM, Kogan MS, Warren HB, Kobzik L, Topulos GP. Nuclear factor-кB p50 limits inflammation and prevents lung injury during Escherichia coli pneumonia. Am J Respir Crit Care Med 2003;168:810-7.

[20] Li Q, Verma IM. NF-kB regulation in the immune system. Nat Rev Immunol 2002; 2:725-34. Erratum in: Nat Rev Immunol 2002;2:975.

[21] Jones MR, Simms BT, Lupa MM, Kogan MS, Mizgerd JP. Lung NF-אB activation and neutrophil recruitment require IL-1 and TNF receptor signaling during pneumococcal pneumonia. J Immunol 2005;175:7530-5.

[22] Takashima K, Tateda K, Matsumoto T, lizawa Y, Nakao M, Yamaguchi K. Role of tumor necrosis factor alpha in pathogenesis of pneumococcal pneumonia in mice. Infect Immun 1997;65:257-60.

[23] Colombel JF, Loftus EV Jr, Tremaine WJ, Egan LJ, Harmsen WS, Schleck CD, et al. The safety profile of infliximab in patients with Crohn's disease: the Mayo clinic experience in 500 patients. Gastroenterology 2004;126:19-31.

[24] Baghai M, Osmon DR, Wolk DM, Wold LE, Haidukewych GJ, Matteson EL. Fatal sepsis in a patient with rheumatoid arthritis treated with etanercept. Mayo Clin Proc 2001;76:653-6. 
[25] Wright TW, Pryhuber GS, Chess PR, Wang Z, Notter RH, Gigliotti F. TNF receptor signaling contributes to chemokine secretion, inflammation, and respiratory deficits during Pneumocystis pneumonia. J Immunol $2004 ; 172: 2511-21$.

[26] Hildebrandt GC, Olkiewicz KM, Corrion LA, Chang Y, Clouthier SG, Liu C, et al. Donor-derived TNF- $\alpha$ regulates pulmonary chemokine expression and the development of idiopathic pneumonia syndrome after allogeneic bone marrow transplantation. Blood 2004;104:586-93.

[27] Tracey KJ, Fong Y, Hesse DG, Manogue KR, Lee AT, Kuo GC, et al. Anti-cachectin/TNF monoclonal antibodies prevent septic shock during lethal bacteraemia. Nature 1987;330:662-4.

[28] Waterer GW, Quasney MW, Cantor RM, Wunderink RG. Septic shock and respiratory failure in community-acquired pneumonia have different TNF polymorphism associations. Am J Respir Crit Care Med 2001;163:1599_ 604.

[29] Wunderink RG, Waterer GW, Cantor RM, Quasney MW. Tumor necrosis factor gene polymorphisms and the variable presentation and outcome of community-acquired pneumonia. Chest 2002;121(3 Suppl):87S.

[30] Cundell DR, Gerard NP, Gerard C, Idanpaan-Heikkila I, Tuomanen El. Streptococcus pneumoniae anchor to activated human cells by the receptor for platelet-activation factor. Nature 1995;377:435-8.

[31] Underhill DM, Ozinsky A. Phagocytosis of microbes: complexity in action. Annu Rev Immunol 2002;20:825-52. 
[32] Kirby AC, Raynes JG, Kaye PM. The role played by tumor necrosis factor during localized and systemic infection with Streptococcus pneumoniae. J Infect Dis 2005;191:1538-47.

[33] Knapp S, Leemans JC, Florquin S, Branger J, Maris NA, Pater J, et al. Alveolar macrophages have a protective antiinflammatory role during murine pneumococcal pneumonia. Am J Respir Crit Care Med 2003;167:171-9.

[34] Marriott HM, Hellewell PG, Cross SS, Ince PG, Whyte MK, Dockrell DH. Decreased alveolar macrophage apoptosis is associated with increased pulmonary inflammation in a murine model of pneumococcal pneumonia. $\mathrm{J}$ Immunol 2006;177:6480-8.

[35] Kolling UK, Hansen F, Braun J, Rink L, Katus HA, Dalhoff K. Leucocyte response and anti-inflammatory cytokines in community acquired pneumonia. Thorax 2001;56:121-5.

[36] Lawrence E, Van Eeden S, English D, Hogg JC. Polymorphonuclear leukocyte (PMN) migration in streptococcal pneumonia: comparison of older PMN with those recently released from the marrow. Am J Respir Cell Mol Biol 1996;14:217-24.

[37] Cohen MS. Molecular events in the activation of human neutrophils for microbial killing. Clin Infect Dis 1994;18(Suppl 2):S170-9.

[38] Biffl WL, Moore EE, Moore FA, Barnett CC Jr. Interleukin-6 delays neutrophil apoptosis via a mechanism involving platelet-activating factor. $\mathrm{J}$ Trauma 1996;40:575-8; discussion 578-9.

[39] Ortqvist A, Hedlund J, Wretlind B, Carlström A, Kalin M. Diagnostic and prognostic value of interleukin-6 and C-reactive protein in communityacquired pneumonia. Scand J Infect Dis 1995;27:457-62. 
[40] Barton BE. IL-6: insights into novel biological activities. Clin Immunol Immunopathol 1997;85:16-20.

[41] Schaaf B, Rupp J, Müller-Steinhardt M, Kruse J, Boehmke F, Maass M, et al. The interleukin-6 -174 promoter polymorphism is associated with extrapulmonary bacterial dissemination in Streptococcus pneumoniae infection. Cytokine 2005;31:324-8.

[42] Bogdan C, Vodovotz Y, Nathan C. Macrophage deactivation by interleukin 10. J Exp Med 1991;174:1549-55.

[43] Latifi SQ, O'Riordan MA, Levine AD. Interleukin-10 controls the onset of irreversible septic shock. Infect Immun 2002;70:4441-6.

[44] van der Poll T, de Waal Malefyt R, Coyle SM, Lowry SF. Antiinflammatory cytokine responses during clinical sepsis and experimental endotoxemia: sequential measurements of plasma soluble interleukin (IL)-1 receptor type II, IL-10, and IL-13. J Infect Dis 1997;175:118-22.

[45] Gallagher PM, Lowe G, Fitzgerald T, Bella A, Greene CM, McElvaney NG, et al. Association of IL-10 polymorphism with severity of illness in community acquired pneumonia. Thorax 2003;58:154-6.

[46] Schaaf B, Boehmke F, Esnaashari H, Seitzer U, Kothe H, Maass M, et al. Pneumococcal septic shock is associated with the interleukin-10-1082 gene promoter polymorphism. Am J Respir Crit Care Med 2003;168:476-80.

[47] Kuhlman M, Joiner K, Ezekowitz RA. The human mannose-binding protein functions as an opsonin. J Exp Med 1989;169:1733-45.

[48] Kaplan MH, Volanakis JE. Interaction of C-reactive protein complexes with the complement system. I. Consumption of human complement associated with the reaction of C-reactive protein with pneumococcal C- 
polysaccharide and with the choline phosphatides, lecithin and sphingomyelin. J Immunol 1974;112:2135-47.

[49] Horowitz J, Volanakis JE, Briles DE. Blood clearance of Streptococcus pneumoniae by C-reactive protein. J Immunol 1987;138:2598-603.

[50] Roy S, Hill AV, Knox K, Griffiths D, Crook D. Research pointers: Association of common genetic variants with susceptibility to invasive pneumococcal disease. BMJ 2002;324:1369.

[51] Roy S, Knox K, Segal S, Griffiths D, Moore CE, Welsh KI, et al; Oxford Pneumococcal Surveillance Group. MBL genotype and risk for invasive pneumococcal disease: a case-control study. Lancet 2002;359:1569-73.

[52] Bergeron Y, Ouellet N, Deslauriers AM, Simard M, Olivier M, Bergeron MG. Cytokine kinetics and other host factors in response to pneumococcal pulmonary infection in mice. Infect Immun 1998;66:912-22.

[53] Dallaire F, Oullet N, Bergeron Y, Turmel V, Gauthier MC, Simard M, et al. Microbiological and inflammatory factors associated with the development of pneumococcal pneumonia. J Infect Dis 2001;184:292-300. Erratum in: J Infect Dis 2001;184:392.

[54] Marik P, Kraus P, Sribante J, Havlik I, Lipman J, Johnson DW. Hydrocortisone and tumor necrosis factor in severe community-acquired pneumonia. A randomized controlled study. Chest 1993;104:389-92.

[55] Moussa K, Michie HJ, Cree IA, McCafferty AC, Winter JH, Dhillon DP, et al. Phagocyte function and cytokine production in community acquired pneumonia. Thorax 1994;49:107-11.

[56] Gon Y, Hashimoto S, Hayashi S, Koura T, Matsumoto K, Horie T. Lower serum concentrations of cytokines in elderly patients with pneumonia and 
the impaired production of cytokines by peripheral blood monocytes in the elderly. Clin Exp Immunol 1996;106:120-6.

[57] Kosmas EN, Baxevanis CN, Papamichail M, Kordossis T. Daily variation in circulating cytokines and acute-phase proteins correlates with clinical and laboratory indices in community-acquired pneumonia. Eur J Clin Invest 1997;27:308-15.

[58] Bonten MJ, Froon AH, Gaillard CA, Greve JW, de Leeuw PW, Drent M, et al. The systemic inflammatory response in the development of ventilatorassociated pneumonia. Am J Respir Crit Care Med 1997;156:1105-13.

[59] Bruunsgaard H, Skinhøj P, Qvist J, Pedersen BK. Elderly humans show prolonged in vivo inflammatory activity during pneumococcal infections. $\mathrm{J}$ Infect Dis 1999;180:551-4.

[60] Montón C, Torres A, El-Ebiary M, Filella X, Xaubet A, de la Bellacasa JP. Cytokine expression in severe pneumonia: a bronchoalveolar lavage study. Crit Care Med 1999;27:1745-53.

[61] Antunes G, Evans SA, Lordan JL, Frew AJ. Systemic cytokine levels in community-acquired pneumonia and their association with disease severity. Eur Respir J 2002;20:990-5.

[62] Fernández-Serrano S, Dorca J, Coromines M, Carratalà J, Gudiol F, Manresa F. Molecular inflammatory responses measured in blood of patients with severe community-acquired pneumonia. Clin Diagn Lab Immunol 2003;10:813-20.

[63] Maskin B, Fontán PA, Spinedi EG, Gammella D, Badolati A. Evaluation of endotoxin release and cytokine production induced by antibiotics in 
patients with Gram-negative nosocomial pneumonia. Crit Care Med 2002;30:349-54.

[64] Millo JL, Schultz MJ, Williams C, Weverling GJ, Ringrose T, Mackinlay $\mathrm{Cl}$, et al. Compartmentalisation of cytokines and cytokine inhibitors in ventilator-associated pneumonia. Intensive Care Med 2004;30:68-74.

[65] Igonin AA, Armstrong VW, Shipkova M, Lazareva NB, Kukes VG, Oellerich M. Circulating cytokines as markers of systemic inflammatory response in severe community-acquired pneumonia. Clin Biochem 2004;37:204-9.

[66] Kellum JA, Kong L, Fink MP, Weissfeld LA, Yealy DM, Pinsky MR, et al.; GenIMS Investigators. Understanding the inflammatory cytokine response in pneumonia and sepsis: results of the Genetic and Inflammatory Markers of Sepsis (GenIMS) Study. Arch Intern Med 2007;167:1655-63.

[67] Calbo E, Alsina M, Rodríguez-Carballeira M, Lite J, Garau J. Systemic expression of cytokine production in patients with severe pneumococcal pneumonia: effects of treatment with a $\beta$-lactam versus a fluoroquinolone. Antimicrob Agents Chemother 2008;52:2395-402. Erratum in: Antimicrob Agents Chemother 2008;52:3828.

[68] Calbo E, Alsina M, Rodríguez-Carballeira M, Lite J, Garau J. The impact of time on the systemic inflammatory response in pneumococcal pneumonia. Eur Respir J 2009 Jul 16 [Epub ahead of print].

[69] Dehoux MS, Boutten A, Ostinelli J, Seta N, Dombret MC, Crestani B, et al. Compartmentalized cytokine production within the human lung in unilateral pneumonia. Am J Respir Crit Care Med 1994;150:710-6. 
[70] Rijneveld AW, Florquin S, Hartung T, Speelman P, van der Poll T. Antitumor necrosis factor antibody impairs the therapeutic effect of ceftriaxone in murine pneumococcal pneumonia. J Infect Dis 2003;188:282-5.

[71] Cundell D, Masure HR, Tuomanen El. The molecular basis of pneumococcal infection: a hypothesis. Clin Infect Dis 1995;21(Suppl 3):S204-11.

[72] Johnston RB Jr. Pathogenesis of pneumococcal pneumonia. Rev Infect Dis 1991;13(Suppl 6):S509-17. 


\section{Table 1}

Chronology of pneumococcal infection in the mouse model

\begin{tabular}{|c|c|c|c|c|c|}
\hline $\begin{array}{l}\text { Infection } \\
\text { (inoculum } 10^{7} \\
\text { CFU) }\end{array}$ & $\begin{array}{l}\text { Step } 1(0-4 \\
\text { h) }\end{array}$ & $\begin{array}{l}\text { Step } 2(4-24 \\
\text { h) }\end{array}$ & Step $3(24-48$ h) & Step 4 (48-72 h) & Step 5 (72-96 h) \\
\hline BAL fluid & $\begin{array}{l}\text { TNF, IL-6, } \\
\text { NO }\end{array}$ & $\begin{array}{l}\text { PMNs, TNF, } \\
\text { IL-6, IL-1 }\end{array}$ & $\begin{array}{l}\text { Downregulation of TNF, IL- } \\
1\end{array}$ & $\begin{array}{l}\text { Monocytes, lymphocytes, } \\
\text { LTB4, NO }\end{array}$ & \\
\hline Tissue & $\begin{array}{l}\text { TNF, IL-6, IL- } \\
1\end{array}$ & $\begin{array}{l}\text { PMNs, TNF, } \\
\text { IL-6, IL-1 }\end{array}$ & $\begin{array}{l}\text { Downregulation of TNF, IL- } \\
1 ; \text { bacteria in tissue }\end{array}$ & & \\
\hline Serum levels & IL-6 & & Bacteraemia & $\begin{array}{l}\text { Reduction in leukocytes; } \\
\text { bacteraemia; TNF, IL-6 }\end{array}$ & \\
\hline
\end{tabular}


CFU, colony-forming units; BAL, bronchoalveolar lavage; TNF, tumour necrosis factor; IL, interleukin; NO, nitric oxide; PMN, polymorphonuclear neutrophils; LTB4, leukotriene B4. 


\section{Table 2}

Cytokines and pneumonia: human studies

\begin{tabular}{|c|c|c|c|c|c|c|}
\hline Reference & $N$ & Mortality & Pneumonia & $\begin{array}{l}\text { Pneumococcal } \\
\text { aetiology }\end{array}$ & Serum cytokines & Timing \\
\hline $\begin{array}{l}\text { Marik et al., } 1993 \\
\text { [54] }\end{array}$ & 30 & $13.3 \%$ & CAP & $14 / 30(47 \%)$ & TNF $\alpha$ & $0,2,6$ and $12 \mathrm{~h}$ \\
\hline $\begin{array}{l}\text { Moussa et al., } \\
1994 \text { [55] }\end{array}$ & 42 & $13 \%$ & CAP & $8 / 42(19 \%)$ & IL-6, TNF $\alpha$, IL-2R $\alpha$ & $\begin{array}{l}1,2,3,4,5,6 \text { and } 7 \\
\text { days }\end{array}$ \\
\hline $\begin{array}{l}\text { Ortqvist et al., } \\
1995 \text { [39] }\end{array}$ & 247 & $3.4 \%$ & CAP & $\begin{array}{c}18(7.3 \%) \text { IPD, } 57 \\
(23 \%) \text { non-BSI }\end{array}$ & IL-6, CRP & $\begin{array}{l}0,2,3,4-5,6-7 \text { and } \\
>7 \text { days }\end{array}$ \\
\hline $\begin{array}{l}\text { Gon et al., } 1996 \\
{[56]}\end{array}$ & 37 & $N / A$ & CAP & $9 / 37(24 \%)$ & $\begin{array}{l}\text { G-CSF, GM-CSF, TNF } \alpha \text {, IL- } \\
8, \text { MIP- } 1 \alpha\end{array}$ & $\begin{array}{l}\text { Acute and recovery } \\
\text { phase }\end{array}$ \\
\hline $\begin{array}{l}\text { Kosmas et al., } \\
1997 \text { [57] }\end{array}$ & 30 & $\mathrm{~N} / \mathrm{A}$ & CAP & $20 / 30(67 \%)$ & $\begin{array}{l}\text { IL-1 } \beta, \text { IL- } 6, \text { TNF } \alpha, \text { CRP, } \\
\text { albumin, fibronectin }\end{array}$ & $\begin{array}{l}\text { 1, 2, } 3 \text { and } 4 \text { days, and } \\
2 \text { days and } 1 \text { day } \\
\text { before discharge }\end{array}$ \\
\hline $\begin{array}{l}\text { Bonten et al., } 1997 \\
\text { [58] }\end{array}$ & 42 & $25 \%$ & VAP & $3 / 42(7.1 \%)$ & IL-6, IL-8 & $-4,-2,0$ and 2 days \\
\hline $\begin{array}{l}\text { Bruunsgaard et al., } \\
1999 \text { [59] }\end{array}$ & 22 & $\mathrm{~N} / \mathrm{A}$ & $C A P+I P D$ & $100 \%$ & $\begin{array}{l}\text { TNF } \alpha, \text { IL-1 } \beta, \text { IL-6, IL-10, IL- } \\
\text { 1Ra, sTNFR-I }\end{array}$ & 0,3 and 7 days \\
\hline
\end{tabular}




\begin{tabular}{|c|c|c|c|c|c|c|}
\hline $\begin{array}{l}\text { Montón et al., } 1999 \\
\text { [60] }\end{array}$ & 20 & $50 \%$ & VAP & $3 / 20(15 \%)$ & $\begin{array}{l}\text { TNF } \alpha, \text { IL-1 } \beta, \text { IL- } 6, \text { CRP in } \\
\text { BAL fluid and serum }\end{array}$ & 1, 3 and 7 days \\
\hline $\begin{array}{l}\text { Antunes et al., } \\
2002[61]\end{array}$ & 24 & $13 \%$ & CAP & $3 / 24(13 \%)$ & $\begin{array}{l}\text { IL-1 } \beta \text {, IL-6, TNF } \alpha \text {, IL-10, IL- } \\
\text { 1ra, CRP }\end{array}$ & 0,3 and 5 days \\
\hline $\begin{array}{l}\text { Fernández- } \\
\text { Serrano et al., } \\
2003 \text { [62] }\end{array}$ & 38 & $28 \%$ & CAP & $17 / 38(44.7 \%)$ & IL-1 $\beta$, IL-6, TNF $\alpha$, IL-10, IL-8 & $0,1,2,3,5$ and 7 days \\
\hline $\begin{array}{l}\text { Maskin et al., } 2002 \\
\text { [63] }\end{array}$ & 24 & $45.5 \%$ & AP & $100 \%$ GNB proven & TNF $\alpha$, IL-1 $\beta$, LPS, IL-6 & 0,4 and $12 \mathrm{~h}$ \\
\hline $\begin{array}{l}\text { Millo et al., } 2004 \\
\text { [64] }\end{array}$ & 9 & $11 \%$ & VAP & $1 / 9(11 \%)$ & $\begin{array}{l}\text { IL-1 } \beta, \text { IL-1 } \alpha, \text { IL-6, TNF } \alpha, \text { IL- } \\
\text { 10, IL-1ra, sIL-1RII, } \\
\text { sTNF } \alpha \text { R-I in serum and } \\
\text { BAL }\end{array}$ & $\begin{array}{l}0,2,4,6,8 \text { and } 10 \\
\text { days }\end{array}$ \\
\hline $\begin{array}{l}\text { Kellum et al., } 2007 \\
\text { [66] }\end{array}$ & 1886 & $\begin{array}{l}35 \% \text { in sepsis, } \\
12 \% \text { in non- } \\
\text { septic }\end{array}$ & CAP & $13 \%$ GPC & TNF $\alpha$, IL-6, IL-10 & $\begin{array}{l}\text { 1, 2, 3, 4, 5, } 6 \text { and } 7 \\
\text { days and weekly until } \\
\text { discharge }\end{array}$ \\
\hline
\end{tabular}




\section{Calbo et al., 2008}

32

$6.1 \%$

CAP

$100 \%$

TNF $\alpha$, IL-1 $\beta$, IL-8, IL-10, IL

$0,1,3$ and 5 days

[67]

6, IL-1ra, CRP

CAP, community-acquired pneumonia; $\mathrm{TNF}_{\alpha}$, tumour necrosis factor-alpha; IL, interleukin; IL-2R $\alpha$, interleukin 2 receptor alpha; IPD, invasive pneumococcal disease; BSI, bloodstream infection; CRP, C-reactive protein; N/A, not available; G-CSF, granulocyte colony-stimulating factor; GM-CSF, granulocyte-macrophage colony-stimulating factor; MIP-1 $\alpha$, monocyte inflammatory protein-1 alpha; VAP, ventilator-associated pneumonia; IL-1 ra, interleukin-1 receptor antagonist; sTNFR-I, soluble tumour necrosis factor receptor I; BAL, bronchoalveolar lavage; HAP, hospital-acquired pneumonia; GNB, Gram-negative bacilli; LPS, lipopolysaccharide; sIL-1RII, soluble interleukin-1 receptor II; GPC, Gram-positive cocci. 